
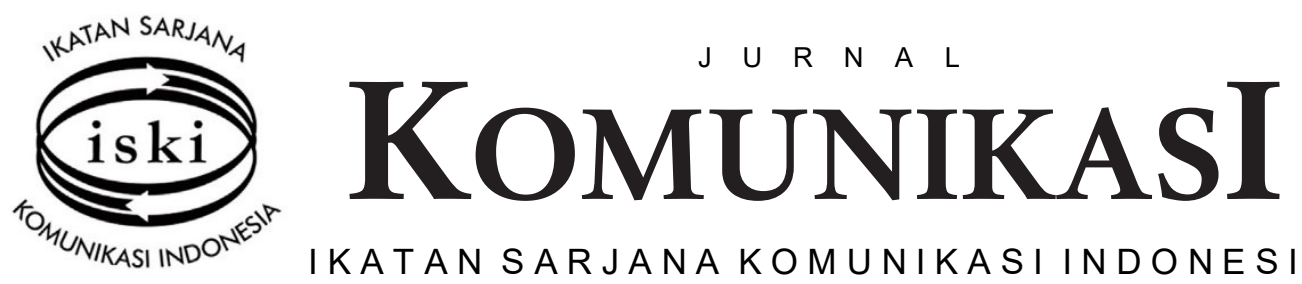

E-ISSN: 2503-0795

P-ISSN: 2548-8740

IKATANSARJANA KOMUNIKASI INDONESIA

\title{
Ethno Gastronomy Simbolic of Indonesian Ethnic Chinese Culture at Jakarta Old Town
}

\author{
https://doi.org/10.25008/jkiski.v4i2.329
}

\author{
Manik Sunuantari ${ }^{*}$, Nurul Haniza ${ }^{2}$, Arry Rahayunianto ${ }^{3,}$ \\ ${ }^{1}$ Faculty of Social and Political Science, Al Azhar Indonesia University \\ J1. Sisingamangaraja No. 2, Kebayoran Baru, Jakarta 12110 - Indonesia \\ ${ }^{2,3}$ Faculty of Communication Science, Sahid University \\ Jl. Prof. Dr. Supomo No. 84, Tebet, Jakarta 12870 - Indonesia \\ *Corresponding author's email: manik.sunuantari@uai.ac.id
}

Submited: 10 July 2019, Revised: 09 August 2019, Accepted: 10 October 2019

Accredited by Kemristekdikti No. 28/E/KPT/2019

\begin{abstract}
One of the ways to increase the country's foreign exchange earnings is encouraging tourism. As one of the countries that is rich in culinary taste of the archipelago, Indonesia has the potential to develop cultural gastronomy as one of the determining factors for tourists to choose tourist destinations. This study aims to determine the symbolic meaning of gastronomy in the culture of ethnic Chinese in Indonesia. The theory used in this study is the symbolic interactionism theory and cultural gastronomy. This study employs a case study method by selecting the Kota Tua (Old Town) area as the research site. Data were collected by means of observation and interviews with informants related to the purpose of the research. The conclusion shows that the Chinese gastronomic culture in Indonesia is the assimilation and acculturation of Chinese and Indonesian gastronomic culture. Thus, it presents culinary tastes that are different from the original, namely Ethno Gastronomy of Ethnic Chinese in Indonesia.
\end{abstract}

Keywords: Ethno gastronomy, Chinese descent, Symbolic interactionism, Acculturation, Assimilation

\begin{abstract}
Abstrak
Salah satu cara untuk meningkatkan devisa negara adalah melalui kegiatan pariwisata. Indonesia sebagai salah satu negara yang kaya cita rasa kuliner nusantara memungkinkan untuk mengembangkan gastronomi budaya sebagai salah satu faktor penentu bagi wisatawan memilih destinasi wisata. Penelitian ini bertujuan untuk mengetahui makna simbolik gastronomi wisata budaya peranakan Tionghoa Indonesia. Teori yang digunakan dalam penelitian ini adalah teori simbolik interaksionis dan gastronomi budaya. Sedangkan metode yang digunakan adalah studi kasus, dengan memilih kawasan Kota Tua sebagai lokasi penelitian. Teknik pengumpulan data dilakukan melalui observasi dan wawancara mendalam dengan nara sumber terkait dengan tujuan penelitian. Kesimpulan penelitian, dalam gastronomi budaya Cina di Indonesia telah terjadi proses asimiliasi dan akulturasi gastronomi budaya Cina dan Indonesia, sehingga memunculkan cita rasa kuliner yang berbeda dengan aslinya, yakni gastronomi budaya Peranakan Tionghoa Indonesia.
\end{abstract}

Kata Kunci: Gastronomi budaya, Peranakan Cina, Interaksi simbolik, Asimilasi, Akulturasi

\section{Introduction}

In addition to a wide range of local culinary varieties, there will be many new culinary finds as a result of China's entry into Indonesia. Chinese culture began to color the lives of Indonesian people, ranging from social life, economics, to a combination 
of culinary offerings. Local cuisines that spread across Indonesia is a mix of flavors and variations of Chinese culture. Even experienced modifications in taste and appearance are related to the tastes of local residents. Some of these cuisines can be found in various tourist destinations in Indonesia, with a variety of flavors, even with new names and appearances that are different from their home countries.

For tourists visiting Jakarta, the name Kota Tua (old town) is familiar, even becoming one of the interesting cultural tourist destinations to visit. Such a large Kota Tua's area provides an opportunity to make Kota Tua an option for culinary trips. Various types of culinary spread around the Kota Tua's area. The various types of culinary, ranging from ancient times to modern culinary can be found in the area. Thus, not only old buildings are worth visiting, but a variety of culinary is stealing the attention of tourists as well.

Destinations should formulate a credible and authentic message about the products they offer to their own food tourism. Experience the journey has changed and is no longer limited to then days of the trip itself, rather we can say that starts much earlier (tourist gets inspired, gather information, compare, buy), and ends when the tourist evaluate the experience and share it through social networks (WTO, 2012).

Thus, communication becomes an inevitable thing in tourism activities, especially gastronomic cultural tourism. Communication messages will be more interesting if packaged with good communication languages so that it can inspire someone to visit the tourist destinations.

The word "gastronomy" was for the first time found in a poem of Jacques Berchoux in 1804. In the definitions made by various authors, gastronomy appears as "research for good eating and drinking", "converting the culture of eating and drinking into art" (Sahin, 2015). As part of tourism activities, gastronomy is one of the attractions of tourists to visit certain tourist sites. A variety of well-packed culinary, and in the form of different services will provide a strong impetus for tourists. The experiences when touring will provide a story for others who want to travel. Gastronomy as a tourism communications research study is one additional factor to increase the number of tourists.

As a country that is rich in diversity of culture, Indonesia gives the feel of exceptional travel to tourists. Communication as one of the elements in tourism activities becomes an integral part of efforts to accelerate the inflow of foreign exchange. The entry of the Chinese nation to Indonesia also colored the cultural treasures of Indonesia, especially in gastronomic cultural tourism.

\section{Theoretical Framework}

\section{Intercultural Communication}

Communication is a process of interaction that involves symbols, and through the symbols meaning is created. In human interaction, people will share symbols that are continuously delivered from one generation to another. Symbols are interpreted subjectively in that a symbol will become a symbol when a number of people agree to make it a symbol. Although all cultures use symbols, the relationship changes and varies.

Various cultures have various symbols that are meaningful, the culture aims to facilitate life by teaching how to adapt to the environment (Samovar, Porter and Daniel, 2010). The term itself «intercultural communication» (ICC) is an integral one. It is related to the research programs of a number of sciences: cultural anthropology, cognitive and social psychology, sociology, cognitive linguistics and language typology (Dimitrova and Chakarova, 2015).

According to Ting Toomey, intercultural communication is a process of symbolic exchange in which two individuals or more different cultural communities negotiate the meanings exchanged in an interactive interaction (Griffin, 2013).

Exchanges between different ethnic symbols will cause problems in building effective communication, so that negotiations will be needed on the meaning exchanged to achieve the expected goals. Intercultural communication as a form of communication that involves interaction between people's perception of culture and symbol systems are quite different in a communication (Samovar, Porter and Daniel, 2010).

Indonesia is rich in diverse cultures, both local cultures that grow from indigenous ethnic Indonesians, and immigrants who provide a variety of colors in the cultural landscape of Indonesia. Various meanings are created together which are the result of negotiations between the parties who communicate. To achieve the expected goals, a mutual agreement is needed, so that the same perception is formed. Symbols as products of the culture of the community will be interpreted differently by other community groups.

A conflict occurs when each party has a different meaning to the symbol of a particular symbol. An 
understanding of the meaning of a symbol will provide perceptual understanding for the communicators. According to Purwasito (Darmastuti, 2013) the basis of intercultural communication are: (1) increasing the intensity and meeting between nations is getting higher, so it is assumed that in this study greater misunderstandings than understanding, (2) with the opening of NAFTA and free trade, it means that many foreigners will come to Indonesia. In other words, there is an increase in the number of meetings between various nations with different cultural backgrounds, (3) the implementation of the regional autonomy policy has separated regional selfishness. Selfishness and all forms of local nationalism can trigger inter-regional conflicts of interest and horizontal conflicts.

Culture and communication cannot be separated. They affect each other. Symbols as cultural products provide common values shared. Values and norms are taught through culture, including the creation of communication symbols. Because of the existence of symbols and emblems, it means there is communication between community members. Cultural background will influence the way someone communicates.

Social interactions that occur in groups or communities become a basic tool in interpreting every event experienced. Through interaction, a shared understanding in a communication event will be built. With an interaction, it is possible to assimilate and acculturate culture.

Assimilation is a social process characterized by efforts to reduce differences between individuals or groups of people. If two groups assimilate, the boundary between groups will be lost and both will merge into one group. Factors that facilitate the occurrence of assimilation: (1) tolerance, (2) balanced opportunities in the economic field, (4) respect for foreigners and their culture, (4) openness of the ruling group in society, (5) equations in cultural elements, (6) inter-marriage, (7) there is a common enemy from outside (Soekanto, 1990).

Openness of existing community groups provides an opportunity for the mixing of cultures, even can add cultural richness. China's entry into Indonesia also adds a new cultural richness of Indonesia, even given the attractiveness for other countries to learn the new culture. Tolerance is required when new cultures enter. The very easy acceptance by society provides a space for Chinese culture to continue to develop by adjusting to the existing Indonesian culture. Chinese and Indonesian cultures are both Eastern cultures, which basically have many things in common. So it is possible for them to blend into each other more easily.

Sometimes assimilation can develop to strengthen acculturation. The resemblance between native culture (immigrants) and indigenous culture may be the most important factor supporting acculturation. The factors that strengthen the acculturation process are personality factors, such as friendship, tolerance, willingness to take risks, cognitive flexibility, openness, and so on. In addition, knowledge about the culture of the indigenous immigrants obtained from various visits before immigrating and interpersonal contact through the mass media may add to the potential of immigrant acculturation (Mulyana, 2006).

Flexibility in the acceptance of immigrant culture, seen in the gastronomic culture of Indonesian tourism, is found in the many mixed cultures of Indonesia and China in various Chinese specialties that enter Indonesia. On the other hand, some Indonesian foods are mixed with Chinese taste, resulting in a taste of the foods that are different from that in their home country. It is undeniable that the number of Chinese immigrants who entered Indonesia in economic, political, social and cultural fields increases.

\section{2.. Symbolic Interactionism in Gastronomy of Chinese Cultural Tourism}

Human activity in life cannot be separated from the symbols, even in the interaction between humans it is very dependent on exchange of symbol. The symbol will bring up the meaning that has been mutually agreed upon. Language is the main tool in the exchange of symbol, through human language that takes various actions. Important concepts in symbolic interactionism include society, self, and mind.

The element of society is related to the ability to construct messages. Through community language formed, individuals as part of the community share messages. Each individual participates in building messages through various symbols. Communication will occur when individuals in the community exchange the symbols so that they form an agreement of meaning.

Community life in groups consists of mutual cooperation behavior, so that in order to be able to cooperate, there must be mutual understanding between its members. Cooperation is the behavior of reading the intentions and actions of others and responding to actions in a good way. Meaning is the result of important communication. The meaning we 
have is the result of our interactions with others. Thus, we cannot communicate with other people without having the same meaning to the symbols we use (Morissan, 2013).

Many people intentionally change the situation to be socially acceptable. Symbols are exchanged to get common understanding. It is also evident that Chinese gastronomy began when the Chinese came to Indonesia by opening a trade route that evolved not only in trade but also in the culinary, even gastronomy. Adaptation is done so that migrants from mainland China can be accepted by Indonesian people. Through interaction it builds unity in community groups, from which the meaning is created together by the parties who communicate. A variety of Indonesian cuisines which eventually blend with Chinese culinary, not only in one generation but have been passed on to the next generations.

The arrival of the Chinese people to Indonesia gave a color to Indonesia's culinary development. Historically, the arrival of the Chinese to Indonesia began when Cheng Ho's fleet sailed in the Ocean in 1421. Boats carried spices from Ternate and Tidore Maluku also carried Chinese porcelain, Chinese ships carried cargo of silk, batik, tin from Malacca and Java. Throughout the archipelago and throughout Southeast Asia, trade was concentrated in Malacca and dominated by the Chinese (Menzies, 2006).

Culture is formed from many complex elements, including religious and political systems, customs, languages, clothing, buildings, and artworks. Culture is learned and is a whole social pattern of human life that has complex, abstract, and broad spacious. Culture is related to trust as a concept that each individual has about how they see his surroundings, both ideas about other people, individuals, nature, surroundings, and about the physical, biological, social and supernatural worlds (Darmastuti, 2013).

Culture is the characteristics and knowledge of a particular group of people, defined by everything from language, religion, cuisine, social habits, music and arts (Padhi, 2016). Culinary culture has been an area that has been ignored until recently. However, culinary culture is always the longest-surviving part of a culture and tradition. To put it in a different way, cuisines where many different identities of a society merge together and national feelings are felt most are a mirror of daily life styles, religious beliefs, habits, traditions and customs (Sormaz et al., 2016).
So that we cannot avoid, that the Chinese nation gives color to various Indonesian cultures. In addition to the language as a cultural product, it is also a cultural food. To create a good food it cannot be separated from the processing of food itself. Food processing as part of gastronomy is also experiencing growth. Gastronomy in Indonesia is also influenced by Chinese culture. It was said (Ketaren, 2017), that gastronomy is "The Art of Good Eating" or in other words is a knowledge and skill about "the art of eating well".

Therefore, gastronomy is arranged according to the stages of art expertise as follows: (1) history includes the origin of raw materials for cooking, how to cultivate raw materials, techniques and presentations, etc; (2) culture includes local ethnic factors (including religion, beliefs, traditional traditions and values of local wisdom) that influence the community to consume these foods, how to eat the local culture, why cuisine is important to the local community, the ability to innovate on components, texture and taste in food and others; (3) geographical landscapes include environmental and climate factors that affect the community to cook these foods, available agricultural products, the level of diversity of local tribes and ethnic migrants that influence local cuisine; (4) cooking methods include techniques and cooking in general, the kitchen equipment used, the prevailing taste of the food and others.

Thus, gastronomy cannot be separated from the influence of culture, especially the culture of the local community. Religions, customs, beliefs, traditions and local wisdom contribute greatly to gastronomic development, which is related not only to food itself but also to ingredients, cooking techniques and serving. Even gastronomy can be used as a basis for understanding certain foods and drinks used in different situations. This is related to the culture of the local community, about their understanding of foods or drinks.

Gerry Philipsen states that culture "socially constructed and histricay is transmitted pattern of symbols, meaning, premisses and rules" (Griffin, 2013). So that culture will influence the way someone communicates in a group. Values and norms provide a guideline on how a person behaves, both with his own group and with other groups. In order to preserve the preservation of a culture, the values are inherited from one generation to another. Even though the interaction process allows the creation of a new culture as a result of the joining or dissolution of one culture. symbol exchange in 
interaction, increases knowledge about real, contemporary communication events in their context (Putra, Putra and Kencanawati, 2019).

With respect to food consumption, the homogenizing aspect of globalization has been attributed to economic forces, particularly because the economic process of trade liberalization makes it possible for food to be sourced from any part of the world (Brokaj, 2014). Globalization has had a lot of impact on culinary development, even culinary has crossed borders between countries. The communication network is able to penetrate the boundaries between countries, including culinary, so as to allow for a gastronomic mix of Chinese cultural tourism in Indonesia.

The exchange of Chinese culture that comes to Indonesia has an impact on various forms of Indonesian cuisine. It even changes the way people eat, what people eat, and how people eat these foods. From the culture, people learn the art of other nations's cuisine and acculturate it into local wisdom. So that it can be said that Chinese culture ultimately gives a new color to Indonesian gastronomy. The examples of dietary habit of Chinese people in Indonesia, thus giving birth to a new gastronomic culture. In general gastronomic studies includes: (1) culture: local ethnic factors including religions, beliefs, traditional traditions and local wisdom values; (2) history: the origin of the cultivation of cooking raw materials and the ability to innovate on components, textures and flavors in food; (3) geographic landscape: geographical \& climate factors and the level of diversity of local tribes and ethnic migrants; (4) cooking method: techniques and cooking in general (Ketaren, 2017).

Thus, gastronomy plays an important role in uniting the cultures of various nations, through communication activities. Therefore, the differences in national cultural identity do not become an issue in national life. Even gastronomy can be an agent in resolving disputes between nations. Political negotiation is held at the dining table to resolve disputes between nations. Cultural gastronomy is able to unite the differences in human views at banquets, regardless of religious beliefs, politics, social status, background origin, social outlook or whatever the story behind it. Through gastronomy it is possible to build an image of the similarities or differences in approaches or behaviors towards foods and drinks which used in various countries and cultures.

Gastronomy is able to build agreement between group members or the communities, so they learn to understand each other. Although they have different cultures, through gastronomy it is possible to assimilate and acculturate culture. Gastronomy is able to facilitate the existing differences, even it will make a possibility for a human to adapt to the external environment.

The process of acculturation in gastronomy allows it to occur if each individual thinks in the collective interest. Migrant communities will soon adapt to the culture of the indigenous people. Likewise, people will easily accept immigrant communities if each of them leaves ethnocentric. Cultural diversity actually becomes a link in establishing community greetings. Strong collectivism will encourage the emergence of new culture as a form of adaptation of two cultures. Although both individualists and collectivists are mindful of social connection and the need of belonging, collectivists put more emphasis on the relationships in the group (Wilczewski, Gut and Gorbaniuk, 2017). So that relationships in groups become a bond that is able to eliminate the existence of individualism. The crossing of culinary culture cannot be separated from the strong individual ties between immigrant culture and new culture.

Gastronomic routes become some of the most advanced products in the field. Gastronomy routes is a system that represents a complete and a thematic tourist offer defined by one or more routes from a particular geographic area (although, in reality, cuisine has no borders) with a number of products or tourism sites such as factories and restaurants, which are listed in tourist guides and revolve around a specific food, product or type of food generally with differentiated quality, and events or gastronomic activities. (Gheorghe,et.al, 2014).

Therefore, a systematic culinary tourism map must be made in the management of a tourist destination. Thematic routes will provide an easy access for tourists to travel. Food products, food types, although they are the same, if packaged differently they will provide a different experience. Gastronomic activities written systematically in tourist guidebooks will give the stimulation to tourists to try. The experiences, which they feel it necessary to tell to others, will push them to try.

\section{Material and Methodology}

This study uses a qualitative approach with descriptive method using a single case study, which is about symbol exchange in communication when there is gastronomic interaction of Chinese culture in Indonesia. According to Mooney (Salim, 2006) that 
descriptive case study research explains the phenomenon under study. Through this research, it is expected to be able to find various symbolic meanings in the gastronomy of Chinese culture in Indonesia.

This research was conducted in Kota Tua destination area, where various gastronomic Chinese cultures are found. A key informant in this study was Aji Chen Bromokusumo, a cultural expert and quiner from Aspertina (Indonesian Ethnic Chinese Association), Head of Cultural Studies \& Preservation (Head of Culture Research \& Aspertina Study). Informants in this study are traders and creators of culinary and visitor communities in the Kota Tua area. Data were collected through in-depth interviews with key informants and informants, nonparticipant observation, and documentation.

According to Bogdan, Miles \& Huberman (Denzi and Lincoln, 2009), data analysis consists of three interrelated sub-processes: data reduction, data presentation, and conclusion/ verification. The method of validating data uses source triangulation. The principle of triangulation comes from navigation, where the intersection of three different reference points is used to calculate the precise location of an object. In research, the principle pertains to the goal of seeking at least three ways of verifying or corroborating a particular event, description, or fact being reported by a study. Such corroboration serves as another way of strengthening the validity of a study (Yin, 2011).

\section{Result and Discussion}

As one of the tourist destinations, the Kota Tua Jakarta is a destination for tourists to visit. In addition to various old buildings in that entire area, including various needs characterized by Chinese culture, it is easy to find and obtain it in the tourist area of Kota Tua. Kota Tua becomes a familiar tourist destination for local and foreign tourists, since it is full of historical values.

Kota Tua area was built during the Dutch colonial rule to become the center of trade in Asia. The city of Jakarta, which at that time was known as Batavia, became the center of trade from and outside the country through shipping routes. There is no doubt that the Kota Tua area is well-known globally. Even the name of Kota Tua is familiar to international tourists.

In addition to being known as a tourist destination, culinary in the Kota Tua area is also one of the tourist attractions of the diverse Indonesian cuisines, ranging from small snacks in the past to large meals that are very interesting to enjoy. Indonesian culinary as one of the cultural products of the Indonesian people has developed quite rapidly. Even Chinese nation get it into Indonesia, adding to Indonesia's gastronomic repertoire.

Various words absorbed from the Chinese language are used for different names of dishes or foods. Most of the Chinese words are derived from the Hokkian dialect in the Ciangchu and Coanciu regions, adding to the Indonesian vocabulary. The Chinese words are also used for the names of various Chinese culinary developments in Indonesia.

Inter-ethnic communication occurs when there is a migration of places or a migration of different ethnic groups to a region or a region that already has different ethnic groups. That is called inter-ethnic communication. When the migrants intend to settle in the area, they need to adapt to the area, both in terms of customs, cultural languages and others (Heryadi and Silvana, 2013).

Thus, the entry of Chinese nation into Indonesia, especially the city of Jakarta, provides its own color to Indonesian culinary variations. Acculturation is unavoidable when migrants try to adapt their taste to that of the indigenous people. Even naming certain foods also experiences a change in the names as indigenous people find it hard to pronounce them. Consequently, some food names adapt to the local market.

Most of the terms and the most influential Hokkien dialect used in Indonesia are derived from the Hokkien dialect Ciangciu and/or Coanciu. In fact, almost all the names or designations used for foods, cuisines, vegetables come from these dialects. But in Indonesia, the pronunciation of the Chinese words is influenced by Cantonese dialect as well as dialects in several regions in Indonesia. But the most influential is the South Chinese dialect. Thus, the interaction occurs when communication is established between the Indonesian people and the immigrant nation that comes from South China.

Through language there is an understanding among the parties who communicate. Signs, symbols, as part of the language, add to Indonesian terms that have been mixed, so that a new language appears. Various Cantonese terms color the naming of basic ingredients, such as: (1) mie, often called bakmi, comes from mian (read: mien), whereas noodles in China actually refers to "noodles with meat", for which it is called noodles. Bak is a Hokkian dialect which means noodles and rou which means meat; (2) bihun, consists of two words, $m i$ fen, which means rice flour. In Hokkien dialect it 
reads bi hun, while in Indonesian it is often called bihun, which means noodles derived from rice flour; (3) sohun, comes from fen se or mi yarn, but other people call it dong fen (read: tung fen) which means winter noodles. In Taiwan it is called tanghun, while in Indonesia it is also called tanghun or xi fen (read: si fen) which means slim mi. Sohun is made of several ingredients such as: green beans, potato tubers, yams, cassava), sago and sugar palm.

Sohun is often used as a complementary meal to eat meatballs, soto, pempek, kimlo; (4) kwetiau, is written in various words. In the original language it is called guo too (read: $k u$ thiau), a type of noodle made of rice flour or wheat flour, wide textured, and widely used in southern China. In Indonesia, there is a lot of fried kuetiau served with vegetables, meatballs, sausages, shrimp, etc. The way of presenting it is different. The people of Medan adopt it from Hokkien culture; (5) misoa, comes from the word mian xian (read: mien sien), which is always served during the celebration of the Lunar New Year. Besides that, it is used during the anniversary which means that with noodles it is expected to be of long life. The texture is soft, supple, and long to describe the age that does not break; (6) wedang ronde, is a unique drink that is familiar to the Indonesian people. The round has a long history, usually presented at the Dongzhi Festival or the Winter Solstice Festival, which is one of the important celebrations according to the Chinese calendar.

The Dongzhi Festival is the last celebration of the whole series of celebrations in Chinese New Year which is the longest night or the shortest day of the year. In China round food is called tang yuan (read: dang yuen) which means ronde sauce. Ronde made from sticky rice flour with small rounds. Colored with bright colors, but most of them are red and white. Ronde is served with sweet gravy or sometimes with meat broth. But sooner or later it was modified with the contents of chopped peanuts, sesame, black beans. In China, the ronde is eaten with no sugar sauce at all, even the sauce tends to be salty.

The meaning of ronde, which is made of sticky rice flour is to strengthen family relationships. In terms of food, ronde has crossed Chinese and Indonesian cultures as a form of cultural assimilation. In its home country of China, ronde is served with savourless with meat broth and rounded rounds without contents, while in Indonesia it is served with sweet sauce plus the aroma of ginger.

The modified wedang ronde only exists in Indonesia, not in other countries. How to serve rounds also varies; (7), Lontong cap gomeh, this food is familiar to the ears of the Indonesian people, served both in roadside stalls and restaurants in luxury hotels. In the place of origin of the Cap Go Meh celebration in China, it is not known as lontong cap go meh. Lontong cap go meh is similar to lontong opor, which is always a mandatory cuisine when celebrating Eid Al-Fitr in Indonesia. It is served with various vegetables, such as lodeh soup, beef rendang, eggs, and serundeng.

In celebrating Eid al-Fitr, ketupat lebaran cuisine is always the main menu among Indonesian Muslim families. Ketupat lebaran is served together with opor ayam, sambel goreng. This dish is a typical Indonesian cuisine that cannot be found in other Muslim countries. Ketupat is sometimes replaced with rice cake because making ketupat is more complicated and takes long time and that it is less practical. Lontong cap gomeh is also served along with opor ayam, ayam abing, fried sauces ati ampela, lodeh, pindang telur. The color of opor ayam uses turmeric as a yellow dye. However, some people do not use turmeric as a yellow dye. Yellow indicates prosperity, because it is identical to gold.

In its development, the gastronomy of Chinese culture in Indonesia has led to assimilation and acculturation of culture, thus giving rise to a new gastronomy, namely the gastronomic ethnic Chinese culture. Various culinary delights in the form of foods and drinks have changed. In their home country, the taste is more salty. With assimilation, the sweet taste gives a variety of new culinary flavors. This is understandable since Chinese migrants initially came to Java which was very dominant with sweetness. Not only the taste but also the way they are served have changed to adjust to local customs. Similarly, lontong cap go meh in its home country, China, is not found since it only exists in Indonesia. Bacang food has also been adjusted, not only its pork content but its chicken and beef content as well.

The process of assimilation and acculturation is inevitable when migrants want the indigenous population to accept them, especially driven by the openness of the indigenous people to accept new cultures from the migrants. The process of assimilation and acculturation in gastronomic cultural tourism can be described as follows: 


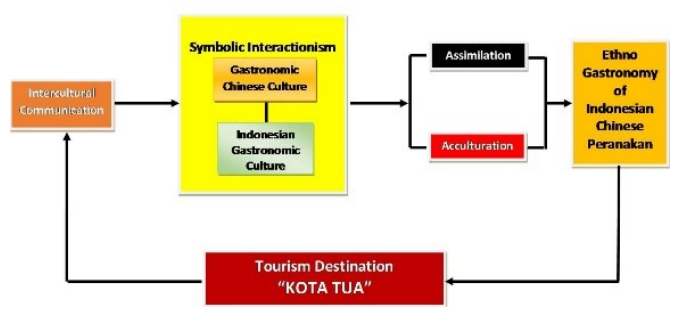

Figure 1. The process of assimilation and acculturation in Ethno Gastronomy of Indonesian Ethnic Chinese

\section{Conclusion}

Based on the results of the study, it can be concluded that in the gastronomy of Ethnic Chinese the process of adapting various cuisines occurs, and so do assimilation and acculturation. The shape and taste of some types of authentic Chinese dishes such as ronde, basket cakes, lapis legit, lumpia (spring rolls) have changed after assimilation. However, lontong cap go meh is a Chinese gastronomic acculturation in Indonesia because this food is not found in other countries.

The assimilation and acculturation is the result of interactions between Chinese migrants and Indonesian people, both in Sumatra and Java. But the dialect which is widely spoken by the migrants is Hokkien. This acculturation also occurs in its development. Chinese words which are difficult to pronounce often makes names different from the original ones. Some of them have adjusted to the Javanese community and others to Sumatran community, thus making interaction and communication between the parties who exchange the messages easy.

As a tourist site, the Kota Tua area has yet to become a favorite tourist destination because its surrounding environment has not been managed optimally. It is necessary to involve stakeholders to develop Kota Tua into one of Indonesia's favorite tourist destinations. Collaboration with various parties is needed to explore the gastronomic potential of the existing heritages by continuing to develop it in such way that it can be accepted by future generations. The importance of understanding cultural gastronomy is inevitable to attract more tourists to visit Kota Tua.

\section{Acknowledgements}

The authors thank to Mr. Aji 'Chen' Bromokusumo, Secretary General of Cultural Research and Study Aspertina (Indonesian Ethnic
Chinese Association) for his meticulous assistance to succeed this research.

\section{References}

Brokaj, M. (2014). The Impact of the Gastronomic Offer in Choosing Tourism Destination: The Case of Albania. Academic Journal of Interdisciplinary Studies, Vol. 3(2): 249-258.

Darmastuti, R. (2013). Mindfullness dalam Komunikasi Antarbudaya. Yogyakarta: Buku Litera.

Denzi, N. K. and Lincoln, Y. S. (2009). Handbook of Qualitative Research (terjemahan). Jakarta: Pustaka Pelajar.

Dimitrova, G. and Chakarova, S. (2015) Intercultural Communication in the Context of Tourism. Cultural Corridor Via Adriatica: Cultural Tourism without Boundaries. SWU "Neofit Rilski" Publishing House: 225-230.

Griffin E. (2013). A First Look at Communication Theory. New York: McGraw-Hill.

Heryadi, H. and Silvana, H. (2013). Komunikasi Antarbudaya dalam Masyarakat Multikultur. Jurnal Kajian Komunikasi, Vol. 1(1): 95-108.

Ketaren, I. (2017). Gastronomi upaboga Indonesia. Jakarta.

Menzies, G. (2006). The Year China Discovered the World. Jakarta. Pustaka Alvabet.

Morissan. (2013). Teori Komunikasi Individu Hingga Massa. Jakarta: Kencana.

Mulyana, D. (2006). Komunikasi Antar Budaya. Bandung: Remaja Rosdakarya.

Padhi, K. P. (2016). The Rising Importance of Cross Cultural Communication in Global Business Scenario, Journal of Research in Humanities and Social Science, Vol. 4(1): 20-26.

Putra, K. D. C., Putra, I. K. M. and Kencanawati, A. A. A. M. (2019). Communicating CSR on Tourism Industry; a Preliminary Case Study of Bali, Jurnal Aspikom, Vol. 3(6); 1182-1199.

Sahin, G. G. (2015). Gastronomy Tourism as an Alternative Tourism: An Assessment on the Gastronomy Tourism Potential of Turkey, International Journal of Academic Research in Business and Social Sciences, Vol. 5(9): 79-105.

Salim, A. (2006). Teori dan Paradigma Penelitian Sosial, Yogyakarta: Tiara Wacana.

Samovar, L., Porter, R. E. and Daniel, E. R. M. (2010). Communication Between Cultures (terjemahan). Jakarta: Salemba Humanika.

Soekanto, S. (1990). Sosiologi Suatu Pengantar. Jakarta: Raja Grafindo.

Sormaz, U. et al. (2016). Gastronomy in Tourism', 
Procedia Economics and Finance. The Author(s), Vol. 39: 725-730.

Wilczewski, M., Gut, A. and Gorbaniuk, O. (2017). The impact of individualism-collectivism orientation and communal orientation on employees' attitudes toward intercultural communication: The case of chinese employees in an MNC, Journal of Intercultural Communication.

WTO, (2012). Global Report on Food Torism. Madrid.

Yin, R. K. (2011). Qualitative Research from Start to Finish. New York: Guilford Press. 